\title{
The effectiveness of policy communication in promoting \#KangPisMan program among university students
}

\section{Heni Nuraeni Zaenudin}

Department of Communication, Faculty of Social Science Education, Universitas Pendidikan Indonesia, Indonesia

Email:heni.nuraeni@upi.edu

Rika Sartika

Department of General Education, Faculty of Social Science Education, Universitas Pendidikan Indonesia, Indonesia

Email: rikasartika@upi.edu

Muhammad Endriski Agraenzopati Haryanegara

Department of Communication - Master Program, Faculty of Communication Science, Universitas Padjadjaran, Indonesia

Email: muhammad20207@mail.unpad.ac.id

\section{Abstract}

This study is aimed at measuring the effectiveness of policy communication in promoting \#KangPisMan program among university students. \#KangPisMan is a top priority program of Bandung Municipal Government to tackle waste management problem. In this sense, the problem of plastic waste has become a global concern about environment, therefore it is a hope that, by promoting \#KangPisMan, a new lifestyle will make people more aware of 
environmental sustainability. The program was established in 2018, so it is necessary to measure the effectiveness of its communicating strategy. In terms of public communication, the realization of promoting the program should be measured based on its optimal value. The present study seeks to analyse the effectiveness of communication strategy by employing $7 \mathrm{C}$ concepts as introduced. The questionnaire was distributed to 300 respondents (based on purposive sampling) which were registered as students of Faculty of Social Sciences Education, Universitas Pendidikan Indonesia. Validity of the questionnaire is measured by corrected item-total correlation. The analysis shows that communication strategy in promoting \#KangPisMan was relatively effective by considering the lowest scores of continuity and consistency. It shows that the aspect of consistency in promoting the program should be enhanced. Meanwhile, the aspect of credibility had the highest value. Therefore, it is a big capital to promote the program through the role model as reflected by the team. In general, all respondents were satisfied of the communication strategy in promoting the program. However, the effectiveness is still potential to be developed in the upcoming time.

Keywords: Communication, Effectiveness, Environment, Kangpisman, Strategy

\section{INTRODUCTION}

Waste, specifically on plastic waste, is a significant global issue. A recent study stated that Indonesia is the world's second-largest contributor to plastic pollutants in the oceans (World Economic Forum, 2020). It is caused by, as stated by Wanda (2019), ineffective waste management on land-based waste management, coastal, and ocean waste. The problems in waste management have also been major problem for Bandung Municipal Government. In the middle of changing the management, on 21 February 2005, the Leuwigajah dumpsite, Bandung, had catastrophic waste avalanche (Lavigne, Wassmer, Gomez, et al, 2014). The accident killed 157 people and buried 71 houses. The day when the accident happened is now called as The Indonesian National Waste Care Day (see Yudiawan, 2017).

In this sense, the government is required to discover practical solution and effective communication in tackling waste management problems. This view is related to the practice of increasing public awareness through publicrelations program. The program is ideally focused on public policy concepts 
as introduced by Ripley \& Franklin (1986) and Dunn (1994). The concept mostly covers (1) stakeholders' perception that the existing phenomenon is a significant problem to be solved; (2) there should be limitation of problem, and (3) organizing constructive support to put the problem as the government's agenda.

Public policy is always related to the function of public-relations function. The reason is that public-relations are generally associated with communication activities designed to form and maintain the image and relationship of the institution with the public. Lattimore, Baskin, Heiman \& Toth (2009) revealed that the recent communication practice has transformed to promote environmental and business elements. As the consequences, each institution is required to re-masure the communication process and the strategies of communication (Prindle, 2011).

In 2018, Bandung Municipal Government revisited waste management issues. A program called \#KangPisman was launched to tackle waste problems in Bandung. The program is believed to provide a practical solution in proper waste management. A proper waste management will create proper culture in society, so it is possible to community to contribute in solving the existing waste problems (Ispranoto, 2018).

\#KangPisMan is a social campaign conducted by Bandung's publicrelations officer in 2018. It is intended to be a collaboration program between the government, citizens, private sectors, and related parties in structuring more advanced waste management through KANG (kurangi/reduce the waste), PIS (pisah/separate the waste), and MAN (manfaatkan/take benefit from the waste). The program is also a response to the fact that Bandung donates 1,500 tons of plastic waste in a day (Bandung Municipal Government, 2018). Waste management is also related to the aesthetic value of a city, therefore the government is consider to issue the Regional Regulation (perda) 11/2005 on city order, cleanliness, and beauty. The regulation contains sanctions that apply to individuals, business, and other institutions that are found to be violating the regulation. The sanction can be in the form of fine of Rp. 250,000 - Rp. 5.000.000. The regulation authorizes the Public Order Agency (Satpol PP) to impose fines on violators.

\#KangPisMan is intended to be a social movement. To create a social movement, it is necessary to implement proper public communication strategy in promoting a certain program. Therefore, the implementation of certain strategies conducted by Bandung's public-relations officer should be examined 
to see the effectiveness of transferring information and public perception regarding the program.

A specific program that has positive public perception can be considered to be a qualified program. According to data from 2010-2014 on the implementation of the PRSA Silver Anvil, it showed that public-relations programs with a high level of appreciation were only $4,2 \%$. The fact reflects the necessity to strengthen programs with public involvement by measuring its effectiveness and public satisfaction (Watson \& Noble, 2007).

The measurement of programs on policy communication is once more important. A classic study by Lindenmann (1993) showed that 57,4\% of respondents believed that the outcome of a public-relations program is measurable and $75,9 \%$ of respondents agreed that a specific study could be conducted to uncover professional policy communication strategies as part of program planning. The findings was based on responses provided by 945 potential respondents from large companies, wholesalers and professional associations, large non-profit organizations, and 20 consulting and academic institutions in the field of public-relations.

Prior studies have shown the analysis on environmental campaign conducted by Bandung Municipal government. Perbawasari, Sjoraida, \& Lestari (2016) have displayed a fact that the government has performed an effective strategy in transferring information. Unfortunately, no evaluation has been performed in regard with the implementation of the program. The evaluation is always necessary no matter the program get positive or negative perception.

A research team from Bogor Agricultural University has also measured the effectiveness of policy communication on yard optimization Program. The study employed different effectiveness parameters, namely cognitive, affective, and conative functions. Based on questionnaire distributed to 100 respondents in Mulyasari Village, Karawang Regency, it can be concluded that the effectiveness of policy communication can be regarded to the achievement of government's objectives (Permana, Sarwoprasodjo, Susanto, \& Saleh, 2011). In addition, Asmuni, Hussin, Khalili, \& Zain (2015) show the role of retail stores and convenience stores in reducing plastic waste in Malaysia through the concept of communication. 45 volunteers in three consecutive days have identified that $52,3 \%$ of consumers has successfully reduced the massive use of plastic bags.

The present study focuses on the effectiveness of policy communication in promoting \#KangPisMan among university students. It is based on the 
assumption that the effectiveness of public communication is underpinned by the increase of public knowledge as the result of transferring information.

\#KangPisMan is a social movement intended to be a practical solution to create zero waste lifestyle as stated in the vision and mission of the Bandung Municipal Government in 2018-2023 (Solehudin, 2019). Based on preliminary identification, Instagram account @kangpisman until March 3, 2019 has 4.020 followers. This is certainly not comparable to the large population of Bandung City, which amounts to 2,503,708 people (Bandung City Central Bureau of Statistics, 2019). Thus, the effectiveness of this program needs to be reviewed whether it has a big impact, especially on student groups as one of the largest internet users (APJII, 2019).

This study is aimed at measuring the effectiveness of policy communication in promoting \#KangPisMan program among university students. By doing so, the results of study are expected to provide significant inputs and valuable feedbacks for the betterment of the upcoming programs. Figure 1 is the example of \#KangPisMan media promotion.

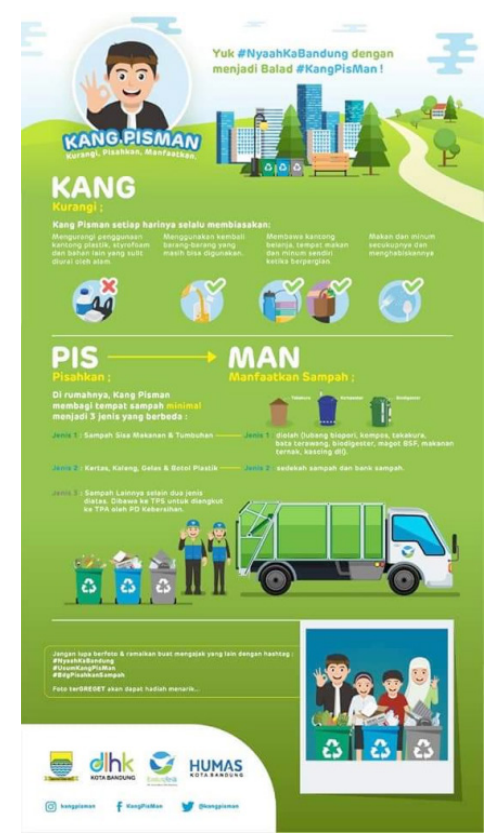

Figure 1: \#KangPisMan media promotion

The present study also considers the recent development of public-relations functions. It is a fact that public-relations now put its attention to environmental 
sustainability in a certain organization. Environmental sustainability issues are related to theories and implementation of public-relations function. Rivero \& Theodore (2014) have explained that environmental, sociological, and institutional elements need to be promoted proportionally to the external and internal public through the use of public-relations efforts to provide updated information to stakeholders and the public.

This is the focus of the present study since \#KangPisMan is closely related to Sustainable Development Goals (SDGs) launched by the United Nations to ensure sustainable consumption and production patterns. A related goal is to substantially reduce waste production through prevention, reduction, recycling, and reuse in 2030.

\section{LITERATURE REVIEW}

In general, communication can be defined as the process of delivering communicators to communicants in order to convey information or to change attitudes or behaviour (Effendy, 2000). Effective communication can be labelled to the situation where someone succeeds in conveying the intended information. Sharon (2017) in more specific explanation states that effective communication can be labelled to the situation where the stimulus and the intended information provided by a speaker is perceived and understood by the interlocutor.

According to Cutlip, Center, \& Broom (2008), there are three elements of communication, namely communicator, message, and interlocutor. Effective communication requires efficiency from all parties on these three elements, taking into account the main principles in implementing public relations programs through $7 \mathrm{C}$ elements in the communication process, including: Credibility, Context, Content, Clarity, Continuity and Consistency, Channel, and Capability of the audience (Cutlip, Center, \& Broom, 2008; Sharon, 2017).

Policy dissemination is important in realizing common perceptions. However, in the governmental context, it is necessary to minimize communication patterns that are still elite-centric and only focus on the political elite (Pratamawaty, Dewi, \& Trulline, 2019). Disseminating policies implemented by an institution and implementing relevant program development for community development are a form of corporate responsibility to the public (Wasesa \& Mcnamara, 2005). This responsibility also needs to be considered by 
government. The respective analogy can also be applied to the implementation of policy dissemination performed by government.

Credibility is the perception of a person or group of people on source of information. In communication process, the credibility factor significantly determines the success of a communication process, especially the persuasion process. People will be more easily influenced by people who are considered to have credibility. There are three factors that shape credibility, namely expertise, trustworthiness, and attractiveness (Nuraeni, Sukarelawati, \& Fitriah, 2015; Winoto, 2015). The credibility component is activated by mutual trust between two parties in communication setting. Credibility can result effective communication in the sense that public perceive positive perception on the dissemination program based on the speaker's credibility (Sharon, 2017). Communication does not occur in a vacuum, but in a particular context or situation. Broadly speaking, the contexts in terms of external factors consist of: first, aspects such as climate, weather, air temperature, room shape, colour, place arrangement, number of participants, and available tools to convey a message; second, psychological aspects, such as: attitudes, tendencies, suspicions, and emotions of communication participants; third, social aspects, such as: group norms, social values, and cultural characteristics; and fourth, the aspect of time, namely when is the right time to communicate (Mulyana, 2014).

Context is a condition in which a situation occurs. Physical context includes rooms, real objects, scenery, and so on. Context, by referring to sociopsychological factors, is related to factors such as the status of the people involved in the communication relationship, their role, and the level of seriousness. Communication context consists of: physical context, social context, historical context, psychological context, and cultural context (Mulyana, 2014). Cutlip, Center, \& Broom (2008) have argued that the context in policy communication must reflect actual fact. The context component can be said to be effective when the community get clear information of a certain program.

The content component must have a certain meaning for the interlocutor and must relate to the recipient's situation (Sharon, 2017). The effective content must provide clear, appropriate, and accountable information to the target community. The dissemination of program must be interesting and allows the interlocutor to understand the information.

Clarity is related to the arrangement of information in the form of understandable sentence structures for the interlocutor. The clarity should be implemented through simple terms. The simple terms can be more 
understandable and do not provide misunderstanding issues. The clarity component can be said to be effective if it provides information to the public by using simple language or words so that it is easy to understand and makes people interested in implementing a program (Sharon, 2017).

Continuity is a movement or program that is mutually sustainable and consistent with a specific goal. Continuity and consistency components are never-ending communication processes (Sharon, 2017). The components of continuity and consistency have an effective value in the sense that the community consider that an information dissemination program must be sustainable so that it is not interrupted in one environment. This information can be passed on to other community groups which have not participated in a program.

Channel is a tool used by sources to convey messages to the interlocutor. Channel also refers to the form of the message from the way the message is conveyed. The presentation of the message here is direct message (face to face) or through printed media (newspapers) or electronic media (radio and television) (Mulyana, 2014). The speaker will choose the right channel depending on the situation and the goals to be achieved.

Cutlip, Center, \& Broom (2008) explained that the channel component is a communication channel or communication tool that already exists and must be used. In addition, in the channel component, there are some activities to select channels according to the target public. The used channel can be said to be effective in the sense that people consider that dissemination program uses a lot of media and can support the success of the promotion. The media can be in the form of printed media (brochures, newspapers, and magazines), social media (twitter, facebook, and others) and websites. Thus, the public will be interested in the dissemination program since there are many channels to access it.

The component of capability of the audience is a communication activity that must consider the abilities of the audience. Communication will be highly effective if it is easily understood by the audience (Sharon, 2017). The capacity or ability of the audience is said to be effective if the community consider that in the dissemination program there are sources who understand the needs of the community.

Communication can have a significant influence on the implementation of public policies, where inappropriate communication can have negative impacts or results for the implementation of the policies. The dimensions of 
communication that can have an influence on the implementation of public policy include: transmission, consistency, and clarity (Ramdhani \& Ramdhani, 2017). The achievement on public policies implementation requires great understanding, clear objectives, and target groups. This concept can reduce the imbalance between planning and implementing program policies. The imbalance issues will result resistance to the respective program (Afandi \& Warjio, 2015).

In general, there are three important things about the policy communication process, namely transmission, consistency, and clarity (Ratri, 2014). Transmission means that public policies are conveyed not only to policy implementers but also to community groups who are the target of the policy and other parties who are direct or indirect stakeholders in the sustainability of the policy. Consistency is related to consistent and clear instructions in implementing the program. It will encourage people who are implementing policies to take appropriate actions in implementing the policy. Clarity requires the unambiguous statements related to purpose, objective, target, and substance of the policy.

\section{METHODS}

This is a quantitative study. Kriyantono (2014) defines quantitative research as a study which describes or explains a problem in which the results can be generalized. It is compatible with the research problems since the researchers are able to see the actual description and facts related to the effectiveness of policy communication in promoting \#KangPisMan program among university students.

The present study was conducted in eight months starting from March to November 2020. The research site was at Faculty of Social Sciences Education, Universitas Pendidikan Indonesia, Bandung. This is in accordance with the research limitations stated in the present study.

The present study employed quantitative research approach, namely field research with statistical data analysis by distributing questionnaires to predetermined respondents. Sugiyono (2014) explains that quantitative research is a method that is often paired with traditional methods, which are scientific, positivistic, and discovery methods. This method is called quantitative since the data are in the form of numbers and the analysis uses statistics. Based on the level of explanation, this research is a descriptive research. It is a research 
aiming at findings facts using appropriate interpretations. Descriptive research seeks to formulate how activities, attitudes, views, and concepts influence a phenomenon happening in the community.

The population in this study were students of Faculty of Social Sciences Education, Universitas Pendidikan Indonesia residing in Bandung. Since there was no real data about students' residency, the sampling was carried out in an infinite population. The criteria of the study were as follows: (1) participants are citizen of Bandung as proven by National Identity Card (shown when filling out the questionnaire), (2) participants are registered as students of Faculty of Social Sciences Education, Universitas Pendidikan Indonesia (proven by showing Student Identity Card), and (3) participants have seen or accessed information related to \#KangPisMan. The sample is part of the number and characteristics of the population (Sugiyono, 2017).

In addition, the determination of samples was based on formula introduced by Lemeshow \& David (1997) with a confidence score of 95\%. The formula resulted score 96,04 so the number of respondents in the present study is 300 respondents. It can be concluded that the respondents in this study were 300 students of the Indonesian Education University (UPI) at the Faculty of Social Science Education. The present study employed probability sampling technique. Sugiyono (2014) explained that, in probability sampling, all elements of the population have equal opportunity to be selected as members of the sample in the study. Sampling in this study used simple random sampling. The determination was based on random population without considering the strata in the population. Those data is taken by using electronic form and validated by each respondent e-mail address that should using @upi.edu or @student.upi. edu domain.

The research was conducted by distributing questionnaire. The questionnaire had been prepared with 20 statements containing $7 \mathrm{C}$ elements from Cutlip, Center, \& Broom (2008). The questionnaire was filled out through paper and pen by respondents. The measurement scale was used to support the results of field research. The technique of making a scale is a technique of sorting in a continuum to quantify data from the measurement of a variable (Ardial, 2014).

The present study used interval scale with Likert model (see Likert, 1932). In the Likert scale, the scale has positive and negative scores in the range of 5-1. Sugiyono (2014) stated that the use of a measurement scale with Likert scale aims to measure the attitudes, opinions, and perceptions of an individual 
or group on a social phenomenon. The Pearson Product Moment Formula (see Pearson, 1895) was used to conduct correlation test. The purpose of using this formula was to determine a quantity that states whether or not the relationship of a variable is strong compared to other variables (Ardial, 2014).

Instrument reliability test can be conducted for internal or external contexts. In external context, the test can be done with test-retest (stability), equivalent, and a combination of both. In external context, consumer reliability can be done by analysing the consistency of the items in the instrument with certain techniques (Sugiyono, 2014). The formula used in testing the reliability of the research instrument was the Cronbach alpha coefficient (see Cronbach, 1951). Besides, in order to validate the instrument, researcher using corrected item-total correlation. This correlation could be used if the item of the instrument are not reaching 30 question items (Kusnendi, 2008).

\section{RESULTS AND DISCUSSION}

At the initial stage, the study was conducted by measuring demographic elements. Based on the data of 300 respondents, it was found that the characteristics of respondents based on gender consisted of 225 female respondents (equivalent to $75 \%$ ) and 75 male respondents (equivalent to $25 \%$ ). The major respondents in this study were female; however, this study does not focus on gender perspective in analysing data.

The variables in this study were focused on the effectiveness of policy communication by using the $7 \mathrm{C}$ elements proposed by Cutlip, Center, \& Broom (2008). The questionnaire had been prepared with 20 statements containing elements of the framework of implementing public-relations including: credibility, context, content, clarity, continuity and consistency, channel, and capability of the audience. The components are required to be measured in order to obtain research findings. The formula says that the average score of variable components above 0,5 reflects ineffectiveness, meanwhile the average score which is equal or greater than 0,5 reflects effectiveness.

The first sub-variable in this study is the element of credibility, which emphasizes public opinion on the credibility of the presented information. In this study, the credibility element is measured by considering three statements and the results are as shown in Table 1. 
Tabel 1: Results on test of credibility and context components

\begin{tabular}{|c|c|c|c|}
\hline $\begin{array}{c}\text { Tests } \\
\text { Components }\end{array}$ & Question & $\begin{array}{c}\text { Mean } \\
\text { (statement) }\end{array}$ & $\begin{array}{c}\text { Mean } \\
\text { (component) }\end{array}$ \\
\hline \multirow{3}{*}{ Credibility } & 1 & 0.78 & \\
& 2 & 0.86 & 0.79 \\
& 3 & 0.73 & \\
\hline \multirow{3}{*}{ Context } & 4 & 0.71 & \multirow{2}{*}{0.75} \\
\cline { 2 - 3 } & 5 & 0.83 & \multirow{2}{*}{0.72} \\
\hline
\end{tabular}

Table 1 shows that each statement submitted in the study have score that can be classified as effective representation. The statement with the highest score in the credibility test component is "Information received by the public can be trusted, such as procedures for reducing household waste" with a mean score of 0.86 . Meanwhile, the third statement regarding information services carried out by the team received the lowest score in the test component with a mean score of 0.73 . The credibility test component has a score of 0.79 which is classified as an effective test component.

The second sub-variable in this study is the context element which emphasizes the public opinion in seeing the program dissemination based on the scope of program discussion and program implementation perceived by public. The results show that each statement submitted in the study has score that can be classified as effective representation. The statement with the highest score in the context test component is "\#KangPisMan is a means of giving suggestion to the Bandung Municipal Government regarding the waste problem" with a mean score of 0.83 . Meanwhile, online and offline dissemination program in order to give information to public received the lowest score with a mean score of 0.71 . The context test component has a score of 0.75 which is classified as an effective test component.

The third sub-variable in this study is the element of content which considers how the audience perceives the content of the information conveyed in the dissemination program series. In this study, the content element was measured by considering three statements and the results were displayed in Table 2 . 
Tabel 2: Results on test of content and clarity components

\begin{tabular}{|c|c|c|c|}
\hline $\begin{array}{c}\text { Tests } \\
\text { Components }\end{array}$ & Question & $\begin{array}{c}\text { Mean } \\
\text { (statement) }\end{array}$ & $\begin{array}{c}\text { Mean } \\
\text { (component) }\end{array}$ \\
\hline \multirow{3}{*}{ Content } & 7 & 0.65 & \\
& 8 & 0.64 & 0.63 \\
\hline \multirow{2}{*}{ Clarity } & 10 & 0.61 & \\
\cline { 2 - 3 } & 11 & 0.65 & \multirow{2}{*}{0.69} \\
\hline
\end{tabular}

Table 2 shows that each statement submitted in the study have score that can be classified as effective representation. The statement with the highest score in the content test component is "\#KangPisMan can provide clear and detailed information about the steps to utilize waste, so that the students can participate" with a mean score of 0.65 . Meanwhile, the respondents put the dissemination program in sub-district areas in Bandung as the lowest score in this component with a mean score of 0.61 . The content test component has a score of 0.63 which is classified as an effective test component.

The fourth sub-variable in this study is the element of clarity which considers how the audience gives perceptions regarding the clarity of information during the program. In this study, the clarity element was measured through two statements and the results were shown in Table 2.

Table 2 shows that each statement submitted in the study have score that can be classified as effective representation. The statement with the highest score in the content test component is "the transferring information performed by \#KangPisMan prioritizes information clarity" with a mean score of 0.73. Meanwhile, the respondents put the transferring information related to procedural aspects as the lowest score with a mean score of 0.65 . The content test component has a score of 0.69 which is classified as an effective test component.

The fifth sub-variable in this study is the element of continuity and consistency which focus on public perception regarding the availability of information and long-term perspective about dissemination program. In this test component, dissemination program is also considered by seeing the consistency of information during the program. In this study, the elements of sustainability and consistency were measured by considering two statements and the results were displayed in Table 3. 
Tabel 3: Results on test of continuity, consistency, and channel components

\begin{tabular}{|c|c|c|c|}
\hline $\begin{array}{c}\text { Tests } \\
\text { Components }\end{array}$ & Question & $\begin{array}{c}\text { Mean } \\
\text { (statement) }\end{array}$ & $\begin{array}{c}\text { Mean } \\
\text { (component) }\end{array}$ \\
\hline Continuity and & 12 & 0.66 & \multirow{2}{*}{0.59} \\
Consistency & 13 & 0.52 & \\
\hline \multirow{4}{*}{ Channel } & 14 & 0.56 & \multirow{2}{*}{0.65} \\
\cline { 2 - 3 } & 15 & 0.64 & \\
\cline { 2 - 3 } & 16 & 0.78 & \multirow{2}{*}{} \\
\cline { 2 - 3 } & 17 & 0.65 & \\
\hline
\end{tabular}

Table 3 shows that each statement submitted in the study have score that can be classified as effective representation. The statement with the highest score in the content test component is "\#KangPisMan performs consistent information dissemination" with a mean score of 0.66 . The continuity and consistency test components have a score of 0.59 which is classified as an effective test component.

The sixth sub-variable in this study is the channel element (information channel) which considers the perceptions of the related audience in which the dissemination program information appears to be in accordance with daily activities. In this study, the elements of the information channel were measured by considering two statements and the results were displayed in Table 3 .

Table 3 shows that each statement submitted in the study have score that can be classified as effective representation. The statement with the highest score in the content test component is "\#KangPisMan utilizes social media (instagram and twitter) to transfer understandable information" with a mean score of 0.78 . The information channel test components have a score of 0.65 which is classified as an effective test component.

The seventh sub-variable in this study is the element of capability of the audience, which considers the audience perceptions regarding how well the information is received by the audience as a whole or partial. In this study, the element of audience capability was measured by considering three statements and the results were displayed in Table 4. 
Tabel 4: Results on test of Capability of The Audience components

\begin{tabular}{|c|c|c|c|}
\hline $\begin{array}{c}\text { Tests } \\
\text { Components }\end{array}$ & Question & $\begin{array}{c}\text { Mean } \\
\text { (statement) }\end{array}$ & $\begin{array}{c}\text { Mean } \\
\text { (component) }\end{array}$ \\
\hline Capability of & 18 & 0.71 & 0.71 \\
the audience & 19 & 0.78 & \\
\hline
\end{tabular}

Table 4 shows that each statement submitted in the study have score that can be classified as effective representation. The statement with the highest score in the content test component is "\#KangPisMan performs online dissemination program which can give information suitable with students' capability in capturing information" with a mean score of 0.78 . The capability of the audience component has a score of 0.71 which is classified as an effective test component. In some of the sections, the researchers have described the partial results by analysing each item and processing each test component. All of the test components measured in the study can be seen in Table 5.

Tabel 5: Results of the calculation of the questionnaire on the overall test components

\begin{tabular}{|cc|}
\hline Tests Components & Mean (component) \\
\hline Credibility & 0.79 \\
Context & 0.75 \\
Content & 0.63 \\
Clarity & 0.69 \\
Continuity and Consistency & 0.59 \\
Channel & 0.65 \\
Capability of the audience & 0.71 \\
\hline Final Average & 0.67 \\
\hline
\end{tabular}

Table 5 shows the average of each component with the credibility component (as the component with the greatest value) has a score of 0.79 . Consecutively, the context component has a score of 0.75 , the content component has a score of 0.63 , the clarity component has a score of 0.69 , the continuity and consistency component has a score of 0.59 (the component with 
the lowest score), the channel component has a score 0.65 , and the capability component of the audience has a score of 0.71 . In general, it can be seen that the final mean of all components is 0.67 .

The average credibility component has the highest score with 0.79 point. The score reflects effectiveness. This component describes the student's assessment of dissemination program on the element of trust in source persons is classified as 'good'. These sources can direct information to the public. The context component has a score of 0.75 . The score reflects effectiveness. This component describes the student's assessment of the accessibility and clarity of content displayed by the team is classified as 'good'. Moreover, the program is also perceived as a forum to construct political aspiration regarding environmental issues.

For the content component, it has a score of 0,63. The score reflects effectiveness. It also indicates that the team has successfully transferred information to public about the program in appropriate method. This can properly support the delivery of information to the target community as a whole and does not get any significant distraction or noise. For the clarity component, it has a score 0.69 . The score reflects effectiveness. The element of clarity includes invitation and information that can be received well by public. The provided invitation and information can attract all elements to engage in the program.

The channel component has a score of 0.65. The score reflects effectiveness. All information channels (offline and online platforms) are employed to support the program dissemination. Even though it has been considered effective, the effectiveness score for offline platform is considered to be lower than online platforms. The existing dissemination program should be strengthened by re-presenting offline advertisements as discussed by the respondents.

The capability of the audience component has a score of 0.71 . The score reflects effectiveness. The team, based on respondents' view, has taken the capability of audience into account of transferring information. The compatibility of message and audience's capability is a key factor in providing well-received information.

The continuity and consistency components have a score of 0,59 . The score reflects effectiveness. The component pays attention to the element of accessibility and availability of information. The respondents consider that 
information regarding \#KangPisMan is gradually difficult to be accessed in public spaces. However, the previous information had a consistent message so public can remember it for a long time. The final average score is 0.67 . It illustrates that the existing dissemination program can be classified as effective but still needs to be enhanced. Given the range of score is $0-1$, the score 0.67 presents a distance from 1 . Even so, the existing dissemination program attracts the element of audience; in this sense, university students.

\section{CONCLUSION}

In general, the findings have answered the research questions. The present study has uncovered a description of the effectiveness of policy communication in promoting \#KangPisMan program. All components show that the program has effective dissemination strategy under the framework of policy communication. The analysis of $7 \mathrm{C}$ components has proven the assumption. However, the statistical results are still potential to be enhanced through the development in dissemination program. By leaning on the results of analysis, the present study proposes some recommendations. The elements of continuity and consistency have the lowest average score; therefore it should be the focus of evaluation for the related parties. As stated by cognitive dissonance theory, humans will focus on attitudes, values, and beliefs depending on how attitudes are formed. Nevertheless, the elements of concept in practical activity have positive perception. For the future studies, the present study can be developed to discuss the performance of dissemination concept in the future time. In addition, the present study can be used as a reference for the government and field officers to make improvements in terms of the consistency of message in encouraging public involvement. At last, it is also potential to discuss digital generation perception about the program through social media activities.

\section{REFERENCES}

Afandi, M. I., \& Warjio. (2015). Implementasi Peraturan Daerah Kabupaten Asahan Nomor 11 Tahun 2011 tentang pajak daerah dalam pencapaian target pajak bumi dan bangunan perdesaan dan perkotaan (Studi deskriptif di Kelurahan Bunut Barat Kecamatan Kota Kisaran Barat). Jurnal Administrasi Publik, 5(2), 92-113.

APJII. (2019). Penetrasi \& profil perilaku pengguna internet Indonesia tahun 2018. Accessed from www.apjii.or.id 
Ardial. (2014). Paradigma dan model penelitian komunikasi. Bumi Aksara.

Bandung City Central Bureau of Statistics. (2019). Statistik Daerah Kota Bandung 2019. Acccessed from https://bandungkota.bps.go.id/ publication/2019/12/04/040296bb302fa5f1d72f53a4/statistik-daerahkota-bandung-2019.html

Bandung Municipal Government. (2018). Laman Resmi KangPisMan Kota Bandung. Accessed from https://www.kangpisman.com/

Cronbach, L. J. (1951). Coefficient alpha and the internal structure of tests. Psychometrika, 16(3), 297-334. doi: 10.1007/bf02310555

Cutlip, S., Center, A. H., \& Broom, G. M. (2008). Effective public relations. Prentice Hall.

Dunn, W. N. (1994). Public policy analysis: an introduction. Prentice Hall.

Effendy, O. U. (2000). Komunikasi: Teori dan praktek. Remaja Rosdakarya.

Ispranoto, T. (2018, October 10). Wali Kota Bandung Kampanyekan "Kang Pisman" untuk Kelola Sampah. Accessed from https://news.detik.com/ berita-jawa-barat/d-4250255/wali-kota-bandung-kampanyekan-kangpisman-untuk-kelola-sampah

Kriyantono, R. (2014). Teknik praktis riset komunikasi (1st ed.). Kencana.

Kusnendi. (2008). Model-model persamaan struktural: Satu dan multigroup sampel dengan LISREL. Alfabeta.

Lattimore, D., Baskin, O., Heiman, S. T., Toth, E. L. (2009). Public relations: the profession and the practice, third edition. The McGraw-Hill Companies.

Lavigne, F., Wassmer, P., Gomez, C. et al. (2014). The 21 February 2005, catastrophic waste avalanche at Leuwigajah dumpsite, Bandung, Indonesia. GEOENVIRON DISASTERS, 1(10), 1-12. doi: 10.1186/ s40677-014-0010-5

Lemeshow, S. \& David, W. H. Jr. (1997). Besar sampel dalam penelitian kesehatan. Gadjah Mada University Press.

Likert, R. (1032). A technique for the measurement of attitudes. Archives of Psychology, 140. 1-55.

Lindenmann, W. K. (1993). An 'effectiveness yardstick' to measure public relations success. Public Relations Quarterly, 38, 7-10.

Mulyana, D. (2014). Ilmu komunikasi suatu pengantar. Remaja Rosdakarya.

Nuraeni, N., Sukarelawati, S., \& Fitriah, M. (2015). Hubungan antara kekuatan 
kredibilitas komunikator dalam komunikasi interpersonal dengan kepuasan pelanggan di Rancamaya Golf dan Country Club di Kabupaten Bogor. Jurnal Komunikatio, 1(1), 1-15. doi: 10.30997/JK.V1I1.117

Pearson, K. (1895). Notes on regression and inheritance in the case of two parents. Proceedings of the Royal Society of London, 58. 240-242.

Perbawasari, S., Sjoraida, D. F., \& Lestari, V. A. (2016). Proses public relations dalam program gerakan pungut sampah Pemerintah Kota Bandung. Jurnal Penelitian Komunikasi, 19(2), 95-108. doi: 10.20422/jpk.v19i2.59

Permana, R., Sarwoprasodjo, S., Susanto, D., \& Saleh, A. (2011). Efektivitas komunikasi program optimalisasi lahan pekarangan (Kasus program kawasan rumah pangan lestari di Desa Mulyasari Kecamatan Ciampel Kabupaten Karawang Jawa Barat). Jurnal Komunikasi Pembangunan, 9(1), 20-28. doi: 10.46937/920119038

Pratamawaty, B. B., Dewi, E. A. S., \& Trulline, P. (2019). Model strategi komunikasi politik sosialisasi kebijakan Masyarakat Ekonomi ASEAN di Bandung Barat. Jurnal Kajian Komunikasi, 7(2), 211-228. doi: 10.24198/ jkk.v7i2.23362

Prindle, R. (2011). A public relations role in brand messaging. International Journal of Business and Social Science, 2(18), 32-36.

Ramdhani, A., \& Ramdhani, M. A. (2017). Konsep umum pelaksanaan kebijakan publik. Jurnal Publik, 3(1), 1-12. doi: 10.1109/ICMENS.2005.96

Ratri, D. K. (2014). Implementasi peraturan walikota nomor 36 tahun 2013 tentang kebijakan kota layak anak. Jurnal Ilmu Pemerintahan UB, 1(2), $1-13$.

Ripley, R. B. \& Franklin, G. A. (1986). Policy implementation and bureaucracy. Brooks/Cole.

Rivero, O., \& Theodore, J. (2014). The importance of public relations in corporate sustainability. Global Journal of Management and Business Research, 14(4), 1-5. https://globaljournals.org/GJMBR_Volume14/4The-Importance-of-Public-Relations.pdf

Sharon, H. (2017). Efektivitas komunikasi humas dalam sosialisasi program SIM online oleh Satlantas Polrestabes Surabaya. Jurnal E-Komunikasi, 5(1), 5-13. http://publication.petra.ac.id/index.php/ilmu-komunikasi/ article/view/6152/5649

Solehudin, M. (2019, September 20). Ini Program Kerja Satu Tahun 
Oded-Yana Pimpin Bandung [This is the program in first year of Oded-Yana for Bandung]. Accessed from https://news.detik.com/ berita-jawa-barat/d-4714446/ini-program-kerja-satu-tahun-oded-yanapimpin-bandung/3

Sugiyono. (2014). Metode penelitian pendidikan pendekatan kuantitatif, kualitatif, dan REDD. Alfabeta.

Sugiyono. (2017). Metode penelitian. Alfabeta.

Wanda. (2019). Upaya Indonesia menanggulangi limbah plastik dari Belanda. JOM FISIP, 6(1), 1-12.

Wasesa, A., \& Mcnamara, J. (2005). Strategi public relations. Gramedia Pustaka Utama.

Watson, T., \& Noble, P. (2007). Evaluating public relations: A best practice guide to public relations planning, research and evaluation (Second Ed.). Kogan Page.

Winoto, Y. (2015). Penerapan teori kredibilitas sumber (source of credibity) dalam penelitian-penelitian layanan perpustakaan. Edulib, 5(2), 1-14.

World Economic Forum. (2020). Radically reducing plastic pollution in Indonesia: A multistakeholder action plan national plastic action partnership. WEC.

Yudiawan, D. (2017, February 21). \#klipingPR Tragedi longsor sampah di TPA Leuwigajah [catastrophic waste avalanche at Leuwigajah dumpsite]. Accessed from https://www.pikiran-rakyat.com/bandungraya/pr-01274832/klipingpr-tragedi-longsor-sampah-di-tpa-leuwigajah 394179 ? page $=2$ 